\title{
Digital Games Designed By Prospective Teachers in The Scratch Program Through The Eyes of Mathematics Teachers
}

\author{
Burçin GÖKKURT ÖZDEMİR1, Rabia BASIR², Aleyna BALBAY ${ }^{3}$, Patmanur Meredova ${ }^{4}$, Kübra ÇAĞLAR ${ }^{\mathbf{5}}$ \\ ${ }^{1}$ Assoc. Prof. Dr., Bartın University, Faculty of Education, Department of Mathematics and Science Education, \\ ORCID ID: 0000-0002-1551-0113, Email: gokkurtburcin@gmail.com \\ ${ }^{2}$ Undergraduate student, Bartın University, Faculty of Education, Department of Mathematics and Science \\ Education, ORCID ID: 0000-0003-2928-6922, Email: m.rabiabasir@gmail.com \\ 3 Undergraduate student, Bartın University, Faculty of Education, Department of Mathematics and Science \\ Education, ORCID ID: 0000-0001-5732-7467,Email: aleynablby@gmail.com \\ ${ }^{4}$ Undergraduate student, Bartın University, Faculty of Education, Department of Mathematics and Science \\ Education, ORCID ID: 0000-0003-2229-9616, Email: pmeredovaa@gmail.com \\ ${ }^{5}$ Undergraduate student, Bartın University, Faculty of Education, Department of Mathematics and Science \\ Education, ORCID ID: 0000-0002-9081-7633,Email: kubra.caglar272@gmail.com
}

\begin{abstract}
Scratch is an effective programming tool encouragingproblem-solving skills of middle school students with the help of its advanrages as its ease, richness of their visual characters and all their objects, as well as processing skills. In particular, the fact that research has shown that teaching with Scratch has positive effects on students' mathematical achievements in algebraic expressions indicates that a different teaching method can be used in the field of algebra learning. Therefore, it is believed that the use of mathematics teachers in the lesson by learning this program before service contributes to the students ' learning and love of mathematics. The aim of the research is to examine the views of mathematics teachers about the games designed by the prospective teachers with the program of Scratch. The participants of this study, in which the case study was conducted, were six mathematics teachers. The research process was carried out in three stages. In the first stage, 13 games were designed by prospective teachers about achievements in algebraic expressions. In the second phase, six mathematics teachers were asked to score these games according to the revised rubric of Li et al (2013). In the third stage, teachers' views about the reasons for the scores that they gave to the games. Kappa coefficients were calculated for the scoring compliance among teachers. Qualitative data analysis techniques were used in the analysis of teacher views. In this study, it was revealed that most teachers found the games interesting, comprehensible and instructive/reinforcing. Some teachers found the games original, while others stated that they were classic games that they often encountered. In addition, some teachers emphasized that they could use these games in their lessons, while others stated that they couldnot use them in their lessons for reasons such as missing instructions, code errors, and lack of knowledge of the Scratch program.
\end{abstract}

Keywords: Algebra Teaching, Mathematics Teacher, Prospective Teacher, Scratch

\section{Introduction}

With the development of technology that has existed for the centuries in human life, it has become indispensable for people to benefit from this technology. The use of technology in education, which has become a part of our daily life, has also become inevitable (Altın \& Kalelioğlu, 2015; Kaya, 2019; Yelbay, 2015). This enabled examination for solutions regarding the issue (Keçeci, Alan, \& Kırbağ-Zengin, 2018). According to Akçay and Sayar (2019), technology shows its place in education by making teaching permanent, meaningful and enjoyable, and by differentiating the education-teaching environment. In relation to these, the use of technology in education has provided great convenience and benefit. As an example, Tarman and Baytak (2011) stated that in classrooms, teachers use projectors in addition to the blackboard for visual lesson processing and give students homework to use computers to access wider resources. It can be said that programming and algorithms are mostly used in web-based applications, which are widely used in courses. In addition, as of 2017, technology-supported trainings such as algorithm coding and web programming have been started to be given to students with the CODE Name 2023 project in the youth centers of the Ministry of Youth and Sports in the provinces (Başarmak \& Hamutoğlu, 2019). According to Baki (2014), when a problem is encountered, the steps that determine the solution stages and Research Type: Research Article 
process steps in order to reach a solution are called algorithms. The language used in algorithm teaching is spoken language. Because it is easy to understand without being tied to any programming language. The commands given during the algorithm should be clear, understandable and short (Cited in Arabacioğlu, Bülbül, \& Filiz, 2007).

According to the Turkish Language Association [TLA] (2017), the program is a "set of commands written to make the computer do an operation", while programming is not only an application software, but also a complex program that targets students' thinking skills and makes a great contribution to their cognitive development and it is defined as a process (Kert \& Uğraş, 2009). According to Ersoy, Madran, and Gülbahar (2011), programming is a production process that requires the use of many skills and provides a meaningful whole by bringing together different information. It can also be mixed and abstract etc. It is among the difficult skills to acquire due to its characteristics. Before designing the program, the person dealing with program development creates an algorithm, evaluates it and transfers it to the computer gradually. For this reason, algorithms create the environment for how the transfer of the problem to the computer will take place. The main purpose of solving algorithm problems is to perform basic programming operations such as variable definition and value assignment, decision making, array creation, control structures, counter and loop structures, which are the basic structures of programming. Many of the students have difficulties due to the abstract nature of these basic structures (Lahtinen, Ala-Mutka, \& Jarvinen, 2005). Initially, while programming, a solution to the identified problem should be produced. Then, a way must be found to create communication pattern using this solution by using computer. In this pattern, attention should be paid to understanding thoughts clearly, the perfect grammar and terms. (Papert, 1980; Szlávi \& Zsakó, 2006). According to Pala and Mıhcı Türker (2019), the importance of programming education has started to be noticed more and more in recent years, and studies have been carried out to provide students with programming knowledge. Regarding this programming education, Information Technologies and Software lessons have been started to be given to the students studying at secondary school in 2012, starting from the 5th grade. In addition, it can be said that in recent years, the Higher Education Council (HEC) Teacher Training Program (2018) has given algorithm and programming courses to mathematics teacher candidates studying at the university, which is of great importance in this context.

Akbay, Ataş, and Turan (2015) stated that the programming course has become a part of education as a course adopted by expert educators. Within the scope of these explanations, "Problem Solving, Programming and Original Product Development" is said to be one of the learning areas of the program published by the Board of Education (Ministry of National Education [MoNE], 2017). In this context, it has been determined to gain some skills in the mentioned learning areas and it has been said that Scratch is one of the software that will enable these skills to be gained (Çubukluöz, 2019). At the same time, Scratch has come to the fore as a program recommended for students who are new to coding education or have difficulties (Guzdial, 2004). The dictionary meaning of Scratch is known as scratching and drawing that's why the logo and character consist of a cat (Keçeci et al., 2018). The Scratch program was designed by the Massachusetts Institute of Technology (MIT) in 2007 to teach coding to individuals of all age groups. The program of Scratch, which is an educational programming tool, is a more suitable tool for expressing ideas on educational issues compared to the old programming languages. At the same time, the Scratch programming tool, in addition to its ease, is an effective tool on the reasoning abilities of individuals at the primary school level with the visual characters and objects of Scratch (Shin \& Park, 2014). It is an interactive interface program that works visually with drag and drop logic and a block-based free coding tool (Yllmaz, 2019). The content of the interface program is given in Figure 1. 


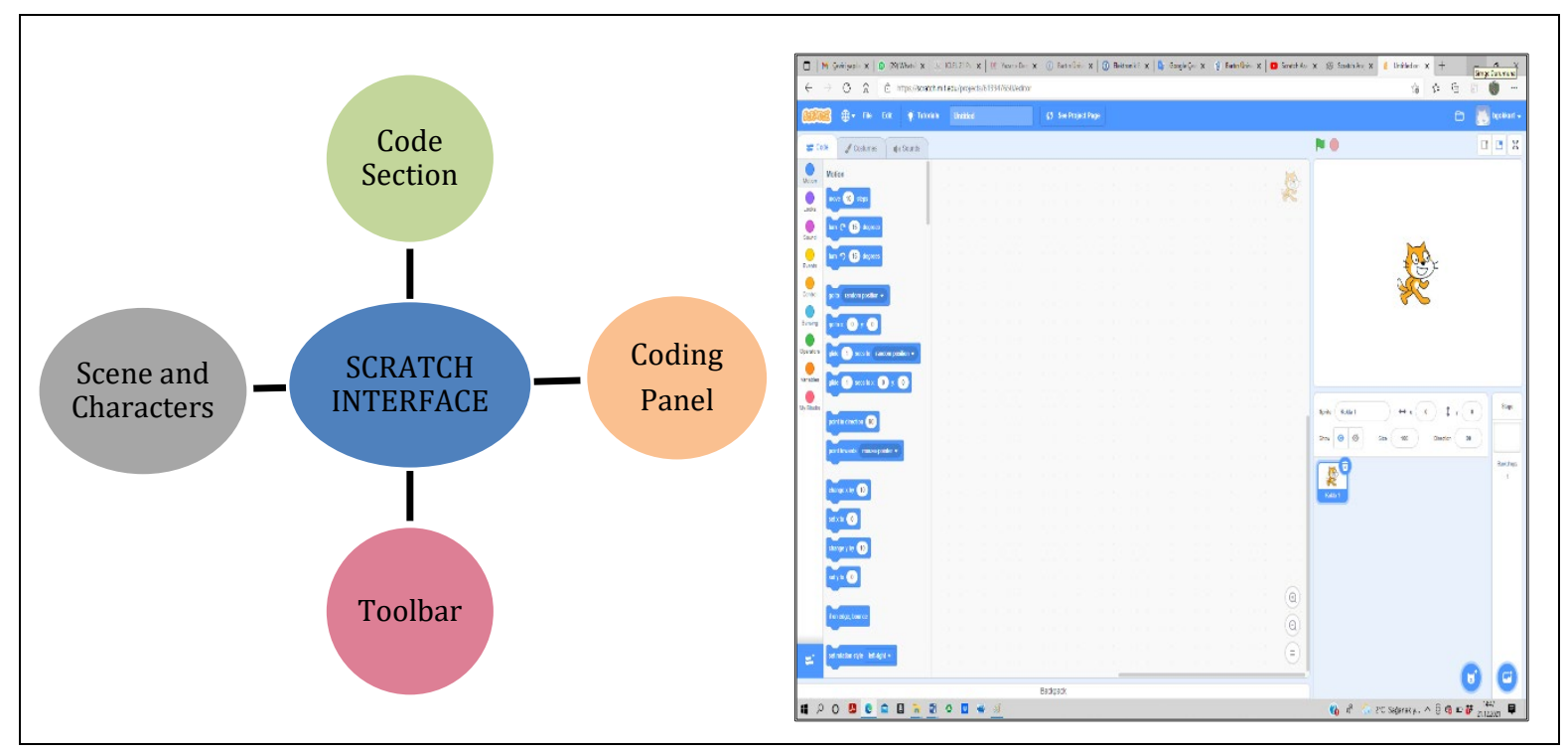

Figure 1. Interface of Scratch Program (Çăğltay \& Fal, 2013)

According to Figure 1, Scratch consists of four basic parts. These are: i) Code section: There are nine command blocks consisting of different colors: motion, appearance, sound, events, variable, control, detection, my blocks and operator. ii) Coding Section: The code consists of three sub-sections: costumes and sounds. iii) Scene and Character: The stage is where the puppet is located and the events take place. In addition, there are signs that allow the start and stop of the event in the upper right part of the stage. iv) Toolbar: It contains many options such as language settings, saving work, file, editing, help, adding and deleting characters, scene size and sharing tabs. When a program coded on a sound block is run in the the program of Scratch, provided that the algorithms are properly sequenced, the sound desired to be heard in the real environment is heard or moved by the options on a dummy console on the screen. With the help of explained features of the program, it is ensured that users gain or develop high-level skills such as problem solving, analysis, creativity, systematic and divergent thinking (Çatlak, Tekdal, \& Baz, 2015). Considering the importance of these skills in daily life, it has been observed that individuals who are more successful in coping with difficulties and reaching their goals are individuals with high-level thinking skills (Yüksel, 2015). According to Aksoy and Küçük-Demir (2019), the use of digital media in mathematics education is one of the important features that increase the level of creative thinking. It is seen that different and creative thinking, which has been mentioned recently, has great importance in investigating reasoning approaches in mathematics education in many respects (National Council of Teachers of Mathematics [NCTM], 1989).

Students have difficulties in learning mathematics (Öztop \& Toptaş, 2017). Mathematics is more abstract compared to other fields (Dienes, 1971; Frenkel, 2013; Sarama \& Clements, 2009). This situation causes difficulties in learning and teaching mathematics (Ramani \& Patadia, 2012). Technological tools have an active role in concretizing mathematical concepts. Especially young children are not ready to work with abstract concepts in terms of their cognitive development. Therefore, if children in this period are taught using technological tools suitable for their cognitive levels, a students' mathematical development can be accelerated and their motivation to learn advanced mathematical concepts can be increased (Köse Yavuzsoy, 2008). Students no longer enjoy working with traditional methods, but with teachers who use technology in their lessons (Özgen \& Obay, 2008). In this context, societies that adopt the traditional understanding of education have difficulties in raising qualified individuals (Obut, 2005). Taşlıbeyaz (2010) and Gelibolu (2009) stated that the use of technology in mathematics teaching determined that it helps to concretize abstract concepts, saves time in the lesson, and increases the students' interest in the lesson. With the increase in the use of technology, research in the field of digital game-based learning has also increased (Sarıçam, 2019). Chuang and Chen (2007) concluded that when educational games are used, the subject to be taught can be given more easily and contributes to the development of high-level thinking skills. Offering meaningful experiences to its users with games, task steps and scenarios that leave a mutual impact; they are entertainment tools that attract more attention to their users with their visual components and sound designs (Varinlioğlu, Alankuş, Aslankan, \& Mura, 2019). The most important factor in making digital games interesting is having fun (Kiili, 2005). According to Prensky (2001), there are many reasons 
why people who play digital games enjoy it and are highly preferred. These games have goals and rules, games give feedback, provide socialization by interacting with other players, and contain a story. One of the prominent games among these games is educational games.

Educational games are games that are used to achieve learning goals and provide learning experiences (De Freitas, 2006). The main goal in educational digital games is to enable students to learn the concepts and information about the subject hidden in the game (Aksoy, 2014). Gee (2014) found it interesting that people insist on passing the part where they have difficulty in computer games and stay in front of the computer for a long time in order to pass that part. For this reason, Gee said that when computer games are used in the teaching, students can learn the subject by having fun. Games are used effectively in many disciplines. One of these disciplines is mathematics. The use of game-supported method in teaching mathematics was found interesting and instructive, especially for primary and secondary school students (Çakmak, 2000). As an example, some studies support the view that block-based games designed with the program of Scratch benefit teachers and students in algebra learning areas, which are thought to be difficult to learn in mathematics lessons. At the same time, these games designed in a digital environment positively affect the success of students in algebra (Mercan \& Aktaș, 2018). According to Akkaya (2006), algebra is an important learning area that always takes place in our lives in understanding the problems encountered in daily life and producing solutions for these problems.

Algebra, which is related to many subjects of mathematics, is an important focus for teaching mathematics at all levels (Lacampagne, 1995). Because the algebra learning process actually starts from arithmetic operations in primary school and then goes to function knowledge. Therefore, if algebra is not learned well in primary and secondary school, it is inevitable to experience problems in gaining further mathematics skills (Eski, 2011). According to Usta and Gökkurt Özdemir (2019), algebra has great contribution to the development of mathematical thinking. Students have difficulties in understanding the concept of variable when they enter the field of algebra learning (Akgün, 2007; Dede, Yalın, \& Argün, 2002; Soylu, 2008;Yalvaç, 2019). Akkaya and Durmuş (2006) stated that the reason for these difficulties is that students do not understand the rules used in arithmetic well and they have misconceptions in operations related to arithmetic. Another reason was stated as students' solving algebra questions without understanding them by heart (Dede \& Argün, 2003). Mercan (2019) emphasized that in teaching algebraic expressions and integers in 6th grade with the help of Scratch program, is of great importance in terms of its effect on a students' motivation, success and permanence of knowledge. It can be said that the reason for this is that an abstract subject such as algebra is made concrete by using the Scratch program instead of the plain expression method, and the student learns by doing and experiencing. The more sense organs the person in the learning position uses, the faster the learning takes place, the easier it is to teach and the more permanent it becomes (Çelik, 2007). In this context, the program of Scratch, colorful visuals, simulation, music, educational games, etc. is used in lessons because it contains elements (Mercan, 2019). It should consider the principle that using visualization in the teaching of mathematics course can affect students positively in the affective and cognitive areas, and visualization should be used in mathematics education from the first to the last stage of primary education (Tutkun, Öztürk, \& Demirtaş, 2011). At the same time, teaching materials are the knowledge, skills and attitudes, etc. that help learning and are desired to be gained for students. It is one of the tools used for the development of the items (Sarıtaş, 2007). In particular, it will be beneficial to use more than one teaching method in mathematics lessons, to provide students with the opportunity to understand mathematics, and to develop and use materials to distract students from rote learning (İnan, 2006).

When the literature is reviewed, it has been seen that there are limited studies (Mercan \& Aktaş, 2018; Mercan, 2019; Öztürk, 2021) using the program of Scratch and the algebra learning field together, but no study has been found on the pre-service teachers' designing games in the field of algebra learning in the Scratch program. However, the use of teaching materials is an important element in increasing the quality of teaching by attracting a students' attention, ensuring their participation in the lesson, getting feedback, etc. Teaching materials are helpful in the realization of many behaviors. Teaching materials are tools that help teachers to convey information to students (Şahin \& Yıldırım, 1999). In the learning process, the use of effective materials will increase the quality and communication in education (Alkan, 1984). These tools and materials used to support learning will make students more willing to learn, and as a result, their success in the lessons will increase. If the acquisitions that should be given to the students is in line with the objectives of the course and are supported with visual and auditory materials, a solid learning will occur (Ertaş, 2006). In this context, it can be said that when the materials used to support teaching are well designed, it facilitates learning by providing reality in the comprehension of what is taught. Gürman (2019) stated in his research that the technology-supported material designed facilitates the learning of students. The Digital Education Plan (2021-2027) emphasizes the development of teachers' digital skills in education and traning (https://ec.europa.eu/education/education-in-the-eu/digital-education-action-plan_en). One 
of the 21st century skills is digital skills, and these skills enable individuals to respond to the requirements of the century, to sustain their lives and to be productive, could be acquired through education (Belet Boyacl \& Güner Özer, 2019). In this respect, it is thought that it is necessary for teachers to acquire effective digital material design skills before they gradute from teacher training programs. In this study, a digital game about algebraic expressions was designed for prospective mathematics teachers in the program of Scratch, and the opinions of mathematics teachers about the games that they designed were taken. The fact that the digital games designed in this study are an instructive resource for students who have problems with algebraic expressions reveals the importance of the research. In addition, students who have negative attitudes towards algebraic expressions can increase their interest in the lesson by playing these digital games.

\section{Method}

In this study, the case study method, as one of the qualitative research methods, was used. A case study is a methodological study that uses multiple data collection to demonstrate the functioning of the limited system and how the study progresses (Chmiliar, 2010). In the case study, a case is investigated in depth and results related to the case are revealed (Ylldırım \& Şimşek, 2008). In the research, using the program of Scratch, the design of digital games related to algebraic expressions in mathematics education and the opinions of teachers about the material were taken, it was deemed appropriate to use this method.

\section{Participants}

The participants of the research consisted of 6 mathematics teachers who were actively working in different state secondary schools in the Western Black Sea Region, which differed in socio-economic terms. appropriate sampling method, one of the purposeful sampling methods, was used in the selection of teachers. In addition, different lengths of service were taken into account in the selection of teachers. Considering the service period of the teachers, the service period varies between $2-20$. The reason why the participants were selected according to different criterias can be shown as the desire to obtain data diversity and richness of results. On a voluntary basis, consent forms were obtained from the teachers, indicating that they participated voluntarily. In terms of the ethics of the research, codes such as T1, T2...T6 were used instead of the real names of the teachers. The service periods of the teachers were as follows: T1: 6 years; T2: 2 years; T3: 12 years; T4: 20 years; T5: 8 years and T6: 7 years. Necessary information was given to the teachers by the researchers about the purpose and content of the study. The teachers were told that this study would only be used for scientific purposes, and it was emphasized that their identity information would be kept confidential.

\section{Data Collection Tool}

As the data collection tool, the Pedagogical Rubrics revised by Li et al. (2013) was used to determine the levels of pedagogical themes in games. A semi-structured A Teacher Interview (TIF) form was used regarding the reasons for the evaluations made by the teachers. The interviews were conducted individually.

\section{Design Process of Digital Games}

Before deciding on the subject on which the Scratch program will be used, the researchers made a needs analysis in the first stage. 


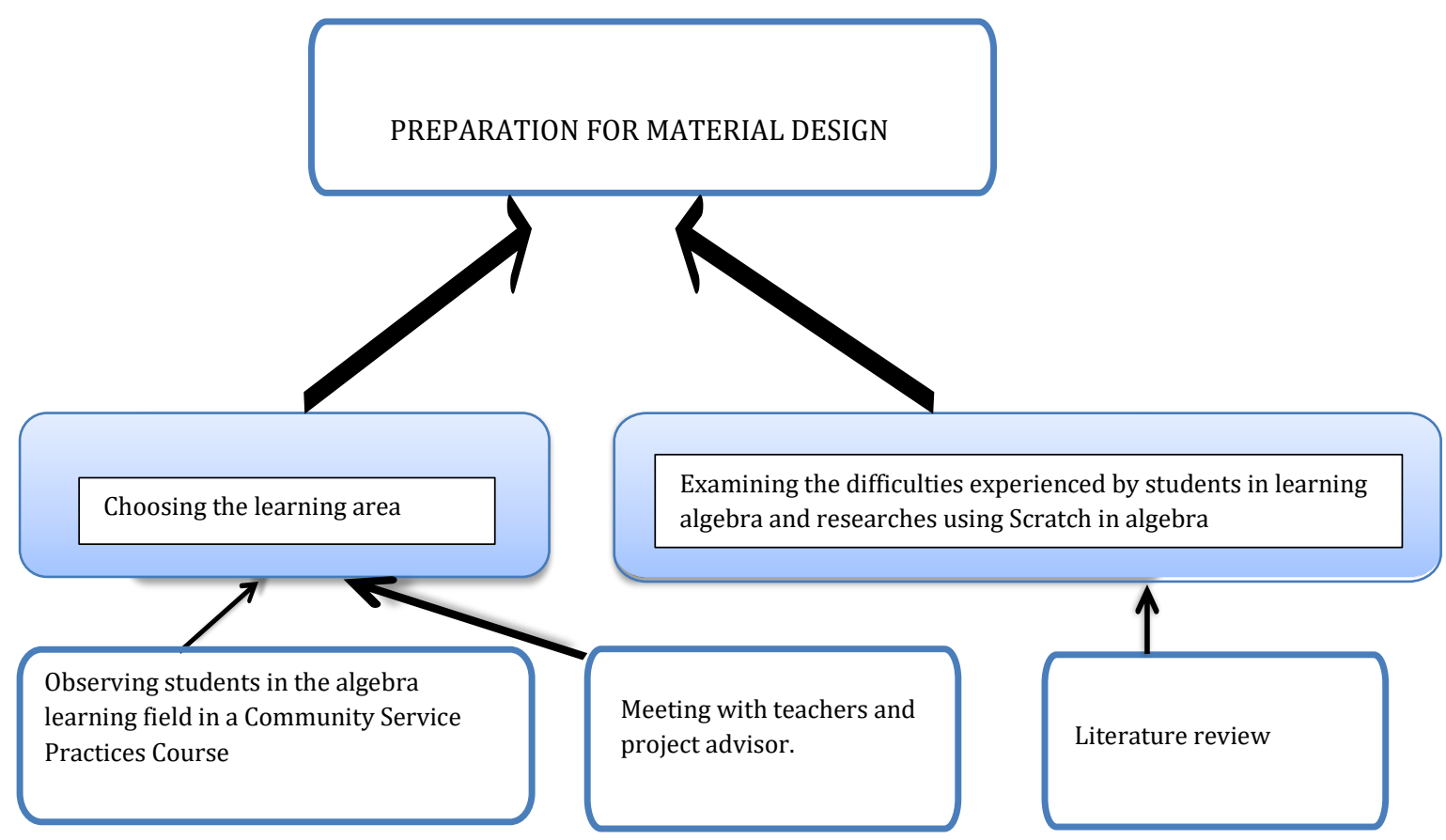

Figure 2. Needs Analysis

As a result of the needs analysis in Figure 2 and the studies in the literature, it was decided to choose the algebra learning area as the learning area. When the literature was examined, it was seen in many studies that students had many mistakes or misconceptions about the area of learning algebra (Akkan, Baki, \& Çakıroğlu, 2012; Akkaya \& Durmuş, 2015; Çelik \& Güneş, 2013; Yıldız, Koza Çiftçi, Şengil Akar, \& Sezer, 2015). In addition to these, studies was found in which teaching using Scratch software contributed to the success of students in learning Numbers and Operations (Çubukluöz, 2019), Algebra (Mercan, 2019) and Geometry (Iskrenovic-Momcilovic, 2020). The fact that the students were generally unwilling and forced to use algebraic expressions during the classroom observations and interviews with the teachers also strengthened this decision.

After the subject was decided, the design process of digital games was started. At this stage, the literature on the program of Scratch was searched and the views of a faculty member who had a doctoral thesis in mathematics education and Scratch on how to prepare digital games on the subject of algebraic expressions in Scratch were consulted. The fact that the researchers received training on the program of Scratch in the Algorithm and Programming course they took in their undergraduate education and that one of the researchers had publications in the field of Scratch facilitated the design process of digital games. In the coding process of the games, attention was paid to include the elements of the games. In addition, it is aimed to create designs that will increase competition among students, encourage them to get the highest score and provide motivation for the mathematics lesson.

During the design process, the researchers presented the games they designed to a faculty member who was an expert in mathematics education and Scratch, and made the necessary corrections in the digital games (eg, the instructions were not clear, the difficulty levels of the questions in the games were the same) in line with the expert opinions. In the study, a total of 13 digital games were designed by the researchers, and the numbers of curriculum objectives (MoNE, 2018) and links of these games are given in Figure 3. Screenshots of some games are also given in Appendix 1. G1, G2, ...G13 codes are used for games. 


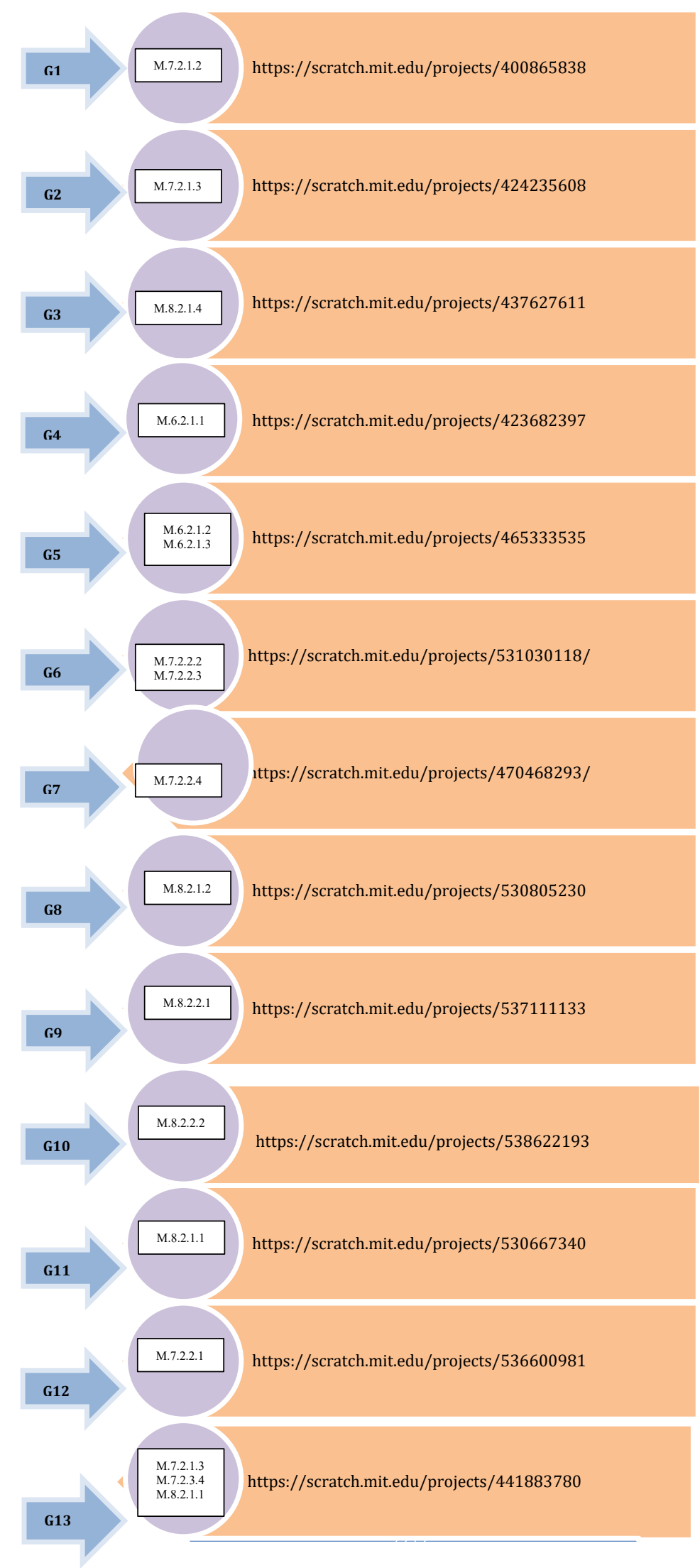

Figure 3. Games Designed for the Achievements in Algebraic Expressions and Links to the Games

Six mathematics teachers were asked to evaluate these digital materials related to the games designed by the pre-service teachers who were in the role of researchers. In this context, the revised Pedagogical Rubric by Li et al. (2013) was used as a data collection tool. In this rubric, there are 13 themes (Problem Solving, 
Exploration and Reasoning, Connection, Strategy, Participation, Interesting, Comprehensible, Educational and/or Reinforcing, Evaluation, Usage, Level, Originality, Duration) and criteria are Less Sufficient (1 point), Sufficient ( 2 points) and Very Sufficient ( 3 points). According to these criterias, the highest score a game can get is $39(13 \times 3=39)$, while the lowest score it can get is 13 . (13x1=13). Teachers were given two weeks for evaluation. After the teachers scored these designed digital games, interviews were held with the teachers regarding the reasons for the scores they gave to these games. Cohen Kappa coefficients were calculated for the concordance level of scoring among teachers (See Table 1). If the Kappa coefficient is less than or equal to 0.20, "poor agreement", between 0.21-0.40 "low agreement", between 0.41-0.60 "moderate agreement", between 0.61-0.80 "good agreement" and 0.81-1.00 between them is interpreted as "very good agreement" (Landis \& Koch, 1977). When the scores of the six mathematics teachers in Table 1 were examined in pairs, generally weak agreement, below-average agreement and moderate agreement were found. Good agreement between T2 and T4 emerged for the G11 game only. Based on this result, it is seen that mathematics teachers' evaluations of games are different.

Table 1. Kappa Values Regarding the Levels of Concordance of Scores Among Mathematics Teachers

\begin{tabular}{|c|c|c|c|c|c|c|c|c|c|c|c|c|c|}
\hline \multicolumn{14}{|c|}{ Value of Kappa } \\
\hline TCHRs & G1 & G2 & G3 & G4 & G5 & G6 & G7 & G8 & G9 & G10 & G11 & G12 & G13 \\
\hline T1*T2 & -.121 & .047 & -.076 & -.018 & -.054 & -.024 & -.006 & .000 & -.016 & -.174 & -.050 & -.044 & -.056 \\
\hline T1*T3 & -.074 & -.070 & -.057 & .023 & .027 & .044 & .082 & .006 & .013 & .064 & .013 & .027 & .014 \\
\hline T1*T4 & .175 & .071 & .086 & .116 & -.014 & -.024 & .043 & -.006 & -.037 & -.037 & -.026 & .065 & -.047 \\
\hline T1*T5 & .099 & .044 & -.040 & -.202 & -.045 & .044 & -.071 & -.073 & -.026 & -.026 & .088 & -.140 & -.156 \\
\hline T1*T6 & .248 & .034 & -.122 & -.044 & -.037 & -.010 & -.075 & .014 & -.045 & -.045 & -.068 & .017 & -.139 \\
\hline T2*T3 & .420 & .097 & .028 & .085 & .133 & .119 & .235 & .000 & -.106 & .133 & .148 & -.182 & -.066 \\
\hline T2*T4 & .387 & .387 & .243 & .058 & .187 & -.182 & -.046 & .000 & .464 & .071 & $.658^{*}$ & .369 & .519 \\
\hline T2*T5 & -.102 & .093 & .142 & -.068 & .173 & -.102 & -.020 & .000 & .019 & .266 & .330 & .297 & .264 \\
\hline T2*T6 & .157 & .152 & .187 & -.123 & .226 & -.130 & -.182 & .000 & .157 & .254 & .286 & .409 & .388 \\
\hline T3*T4 & .278 & .019 & .010 & .032 & .156 & -.102 & -.024 & -.083 & -.061 & -.152 & .133 & -.034 & .097 \\
\hline T3*T5 & -.222 & -.130 & -.444 & -.444 & -.268 & -.300 & -.238 & -.147 & -.147 & -.182 & .235 & -.282 & .177 \\
\hline T3*T6 & .055 & .071 & -.287 & -.051 & -.102 & -.444 & -.477 & -.114 & -.138 & -.209 & .052 & -.232 & .268 \\
\hline T4*T5 & .289 & .055 & .117 & .090 & .090 & .339 & .079 & .071 & .270 & .124 & .435 & -369 & .150 \\
\hline T4*T6 & .350 & .387 & .010 & .179 & .350 & .152 & .081 & .088 & .323 & .187 & .458 & -.093 & .429 \\
\hline T5*T6 & .366 & .323 & .204 & .117 & .052 & .198 & .114 & .085 & .409 & .409 & .103 & .228 & .356 \\
\hline
\end{tabular}

Content analysis technique was used in the analysis of the interview findings with the teachers. Data from content analysis "Word cloud" technique was used to visualize and make it more understandable. The purpose of visualizing data are not to make it aesthetically beautiful, but to make it understandable. Visualization provides quick information to people who are interested in the subject (Fronza et al. 2013). In this context, word clouds were created in the WordArt application related to the codes of the interviews. For the reliability of the research, the interview data were coded separately by two researchers. It was determined that the fit calculated by considering Miles and Huberman's (1994) agreement percentage was fully achieved.

\section{Findings}

In this section, the findings of the research are given under two headings. The first heading represented the findings related to the scores of mathematics teachers for the games designed by pre-service teachers. The second one included the findings related to the explanations of the mathematics teachers about the reasons for their scoring.

Findings on Mathematics Teachers' Evaluations of Digital Games Designed by Pre-service Teachers

Table 2. shows the findings of mathematics teachers' evaluations of 13 themes in the pedagogical rubric

Table 2. Findings Regarding the Evaluation of Digital Games According to Themes in the Pedagogical Rubric

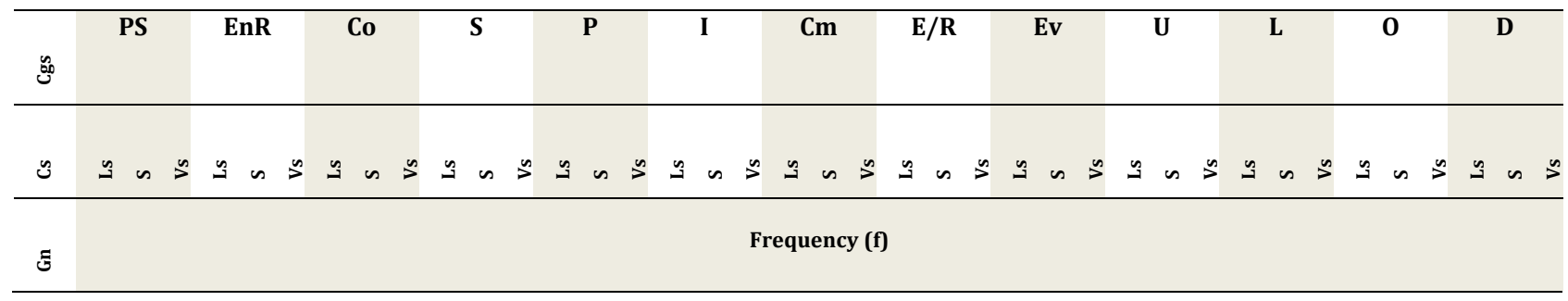




\begin{tabular}{|c|c|c|c|c|c|c|c|c|c|c|c|c|c|c|c|c|c|c|c|c|c|c|c|c|c|c|c|c|c|c|c|c|c|c|c|c|c|c|c|}
\hline 1 & 1 & 3 & 2 & 5 & 1 & 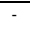 & 5 & 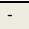 & 1 & 4 & 2 & & 2 & 2 & 2 & 1 & 1 & 4 & & 3 & 3 & & 3 & 3 & 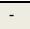 & 3 & 3 & 4 & 1 & 1 & 1 & 1 & 4 & 4 & 2 & 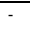 & 1 & 1 & 4 \\
\hline 2 & 1 & 1 & 4 & 2 & 2 & 2 & 4 & 1 & 1 & 3 & 2 & 1 & 1 & 2 & 3 & - & 3 & 3 & & 2 & 4 & & 1 & 5 & 1 & 2 & 3 & 1 & 1 & 4 & 1 & - & 5 & 2 & 2 & 2 & - & 1 & 5 \\
\hline 3 & 1 & 2 & 3 & 2 & 2 & 2 & 2 & 3 & 1 & 3 & 2 & 1 & 1 & 2 & 3 & - & 1 & 5 & & 2 & 4 & 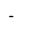 & 2 & 4 & 1 & 1 & 4 & 1 & 3 & 2 & 1 & 1 & 4 & 2 & 2 & 2 & 3 & 1 & 2 \\
\hline 4 & - & 2 & 4 & 2 & 2 & 2 & - & 2 & 4 & 2 & 2 & 2 & 2 & 1 & 3 & - & 1 & 5 & 1 & 1 & 4 & 1 & 2 & 3 & 1 & 2 & 3 & 1 & 3 & 2 & 1 & 1 & 4 & 2 & 2 & 2 & - & 1 & 5 \\
\hline 5 & 1 & 2 & 3 & 3 & 2 & 1 & 2 & 2 & 2 & 3 & 2 & 1 & - & 1 & 5 & - & 1 & 5 & - & 3 & 3 & 1 & 1 & 4 & 1 & 2 & 3 & - & 3 & 3 & 1 & - & 5 & 1 & 1 & 4 & 1 & 1 & 4 \\
\hline 6 & - & 2 & 4 & 1 & 3 & 2 & - & 2 & 4 & 1 & 3 & 2 & - & 2 & 4 & - & 2 & 4 & 1 & 1 & 4 & - & 2 & 4 & - & 2 & 4 & 1 & 2 & 3 & 1 & - & 5 & 1 & 1 & 4 & - & 1 & 5 \\
\hline 7 & - & 3 & 3 & 1 & 2 & 3 & 1 & 3 & 2 & 1 & 3 & 2 & - & 4 & 2 & - & 2 & 4 & - & 2 & 4 & - & 2 & 4 & 1 & 2 & 3 & 2 & 2 & 2 & 1 & 2 & 3 & 2 & 2 & 2 & - & 1 & 5 \\
\hline 8 & - & 2 & 4 & 1 & 3 & 2 & - & 2 & 4 & 1 & 2 & 3 & - & 1 & 5 & - & 1 & 5 & - & 1 & 5 & - & 2 & 4 & - & 2 & 4 & - & 2 & 4 & - & 1 & 5 & 1 & 1 & 4 & - & 1 & 5 \\
\hline 9 & 1 & 2 & 3 & 2 & 3 & 1 & 2 & 3 & 1 & 3 & 2 & 1 & - & 2 & 4 & - & 3 & 3 & - & 2 & 4 & - & 2 & 4 & - & 1 & 5 & - & 2 & 4 & 1 & - & 5 & 1 & 2 & 3 & - & 1 & 5 \\
\hline 10 & 1 & 3 & 2 & 2 & 3 & 1 & 1 & 3 & 2 & 3 & 2 & 1 & 1 & 2 & 3 & 1 & 3 & 2 & - & 1 & 5 & - & 2 & 4 & 1 & 1 & 4 & 1 & 2 & 3 & 1 & - & 5 & 1 & 3 & 2 & - & 1 & 5 \\
\hline 11 & 1 & 2 & 3 & 3 & 2 & 1 & 3 & 3 & - & 3 & 2 & 1 & 1 & 1 & 4 & 1 & 1 & 4 & - & 1 & 5 & - & 2 & 4 & - & 1 & 5 & 1 & - & 5 & 1 & - & 5 & 2 & 2 & 2 & - & 1 & 5 \\
\hline 12 & 1 & 3 & 2 & 2 & 3 & 1 & 4 & 1 & 1 & 2 & 3 & 1 & 1 & 1 & 4 & - & 3 & 3 & - & 2 & 4 & - & 2 & 4 & 1 & 2 & 3 & 2 & 1 & 3 & - & 1 & 5 & 1 & 3 & 2 & - & 1 & 5 \\
\hline 13 & 1 & 2 & 3 & 3 & 2 & 1 & 2 & 2 & 2 & 3 & 2 & 1 & - & 2 & 4 & - & 1 & 5 & & 1 & 5 & 1 & 1 & 4 & & 2 & 4 & - & 1 & 5 & - & 1 & 5 & 1 & 4 & 1 & - & 1 & 5 \\
\hline
\end{tabular}

PS: Problem solving, EnR: Exploration and Reasoning, Co: Connection, S: Strategy, P: Participation, I: Interesting, Cm: Comprehensible, E/R: Educational and/or Reinforcing, Ev: Evaluation, U: Usage, L: Level, O: Originality, D: Duration, Ls: Less Sufficient, S: Sufficient, Vs: Very Sufficient, Cs: Competence Status, Cgs: Categories, Gn: Game number

According to Table 2, it is striking that the teachers mostly found the games coded G6, G8 and G13 very sufficient. On the other hand, it is seen that teachers find the G1 coded game less sufficient. According to Table 2, when the answers given by the teachers to the theme "Problem solving" are examined, it is striking that the games coded G2, G4, G6 and G8 are very sufficient.

When the answers given by the teachers to the theme "Exploration and Reasoning" are examined, it is noteworthy that the games are generally found to be less sufficient. When the answers given by the teachers to the "Connection" theme are examined, it is seen that the G1, G2 and G12 coded games are found to be less sufficient. When the answers given by the teachers to the "Strategy" theme are examined, it is noteworthy that the games are generally found to be less sufficient. The G8 coded game was found very sufficient by three teachers. When the answers given by the teachers to the "Strategy" theme were examined, they generally found the games sufficient and very sufficient. G1, G2, G3, G4, G10, G11 and G12 games were found to be less sufficient in this category. Only three games were found to be less than sufficient. These games are G1, G10 and G11 coded games. When the answers given by the teachers to the "Comprehensible" theme were examined, all but two of the games were found to be sufficient and very sufficient in the intelligibility category. Games that are found to be less sufficient are G4 and G6 coded games.

When the answers given by the teachers to the theme of "Educational and/or Reinforcing" were examined, most of the games were found to be sufficient and very sufficient in the category of Educational and/or Reinforcing. Only three games were found to be less than sufficient by the same participant. The less adequate games are G4, G5 and G13. When the answers given by the teachers to the theme of "Evaluation" were examined, most of the games were found to be very sufficient and sufficient. Games that were found to be less sufficient are G2, G3, G4, G5, G7, G10 and G12 coded games. When the answers given by the teachers to the theme of "Usage" were examined, most of the games were found sufficient and very sufficient. In this category, the game coded G1 was found to be less than sufficient by four participants. When the answers given by the teachers to the "Level" theme were examined, it was seen that most of the games were very adequate. Only G1, G3, G4 and G8 coded games were found sufficient. When the answers given by the teachers to the theme "Originality" are examined, it was seen that the G1 coded game was found to be less sufficient. When the answers given by the teachers to the "Duration" theme were examined, it was seen that the games were very sufficient in terms of time. Table 3 presents the findings regarding the total points given by six mathematics teachers to 13 digital games according to the Pedagogical Rubric.

Table 3. Findings Regarding the Total Scores of the Digital Games from the Pedagogical Rubric as a Result of the Evaluation made by the Mathematics Teachers 


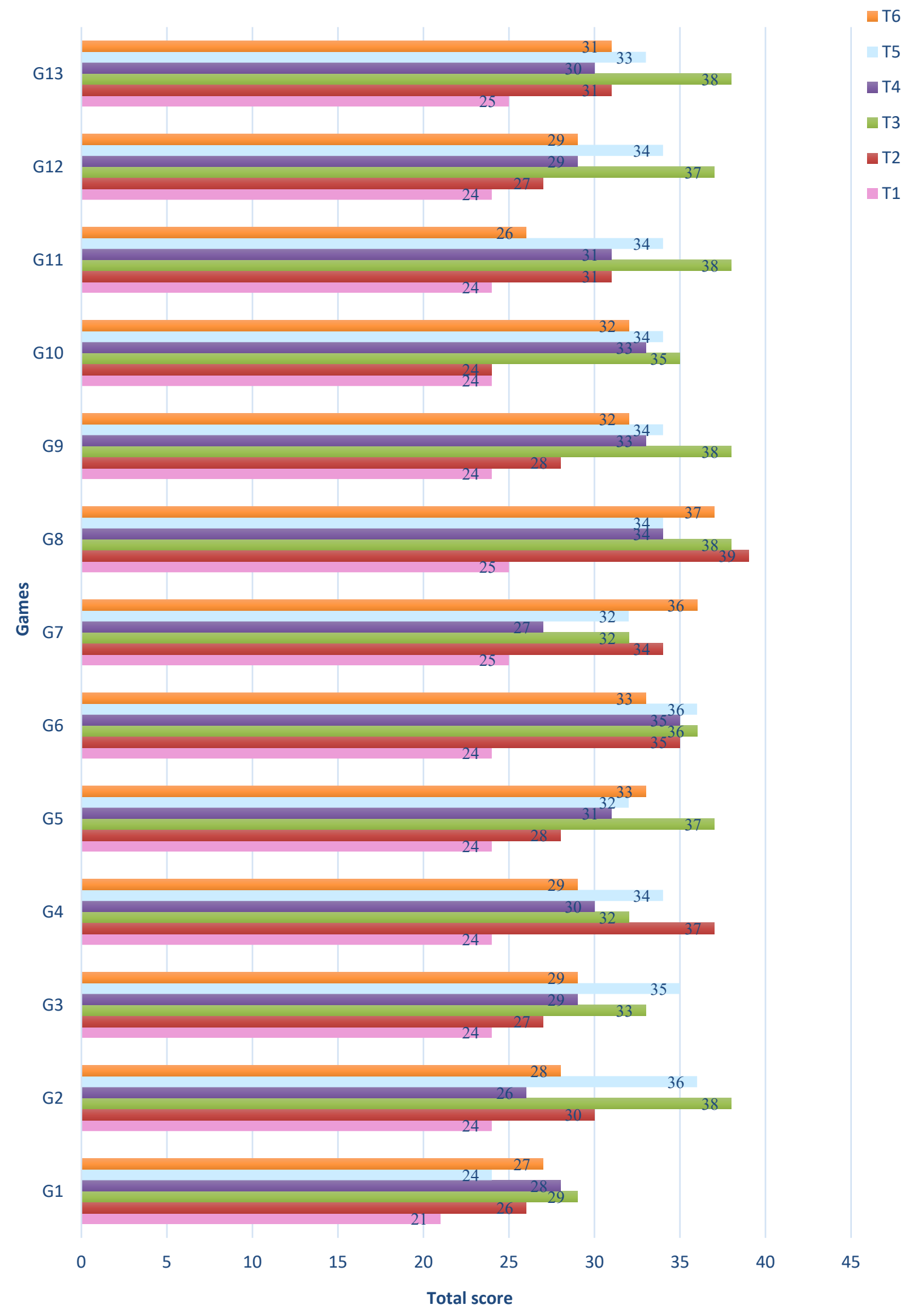

\begin{tabular}{lllllllllllll}
\hline G1 & G2 & G3 & G4 & G5 & G6 & G7 & G8 & G9 & G10 & G11 & G12 & G13 \\
\hline \multicolumn{10}{c}{ Aritmetic Mean } \\
\hline 25.83 & 30.33 & 29.50 & 31 & 30.83 & 33.17 & 31 & 34.50 & 31.50 & 30.33 & 30.67 & 30 & 31.33 \\
\hline
\end{tabular}


When Table 3 is examined, it is seen that the arithmetic mean of the total score they got from the rubric evaluated by six teachers in 12 games is 26 and above. The total score of only the G1 coded game from the rubric is 25.83. Considering that the score value of the adequate criterion, which was one of the evaluation criteria in the rubric is 2 , it could be said that almost all of the games are sufficient. Considering the length of service of the teachers, it was seen that the length of service has no effect on scoring, and they gave similar scores for some games (for example, T2 with the same service period of two years and T6 with 20 years of service give the same score for the G6 game).

\section{Findings of Mathematics Teachers' Statements Regarding the Pedagogical Themes They Scored Digital Games}

In the games, the explanations made by the teachers regarding the problem solving theme are combined in common codes and given as a word cloud in Figure 4.

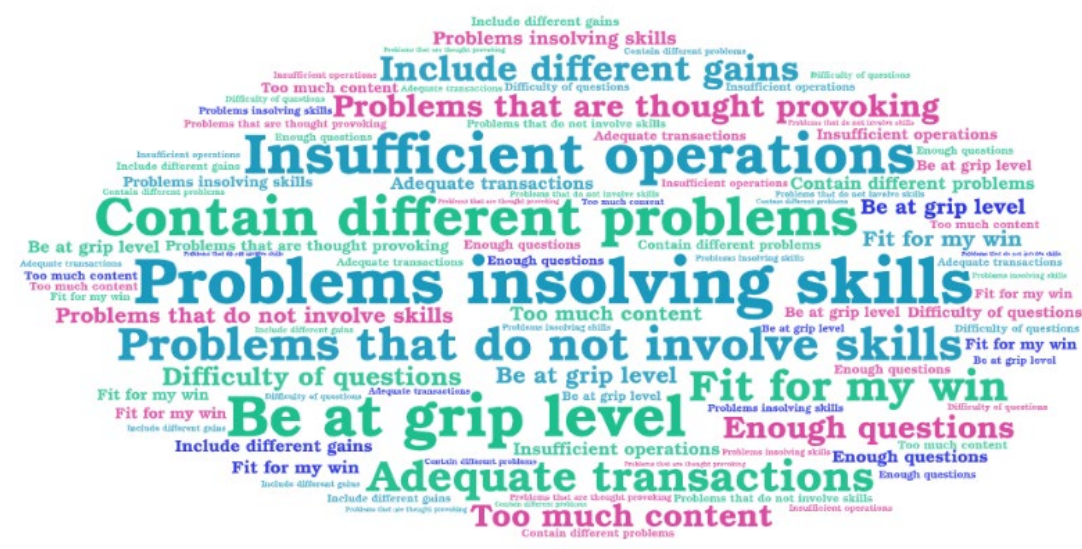

Figure 4. The Word Cloud of Problem Solving Theme

As can be seen in Figure 4, the teachers made some explanations about the reasons for the scores they gave to the problem solving theme in the games. As a result of the content analysis of these explanations, the codes were revealed that the contain different problems, problems insolving skills, insufficient operations, and problems that so not involve skills. Almost all of the teachers (except for one participant) found the games sufficient or very sufficient in the problem solving theme. In the interviews, the teachers generally stated that the games are suitable for problem solving, they improve problem solving, and the problems are skill-enhancing and thought-provoking. When the reasons for finding the games to be very sufficient are examined, it is mentioned that there are different types of content such as factoring with algebraic expressions and identities for the G3 coded game. It is stated that for the G2 coded game, different types of problems are included, such as finding a pattern rule for algebraic expressions, and finding the term in a certain step of the pattern whose rule is given. When the sufficent status of the games is examined, it is mentioned that there is no connection between the process and the event for the G5 coded game. They stated that for the G1 coded game, questions about algebraic operations should be increased. In the games, the explanations made by the teachers regarding the discovery and reasoning theme are combined in common codes and given as a word cloud in Figure 5. 


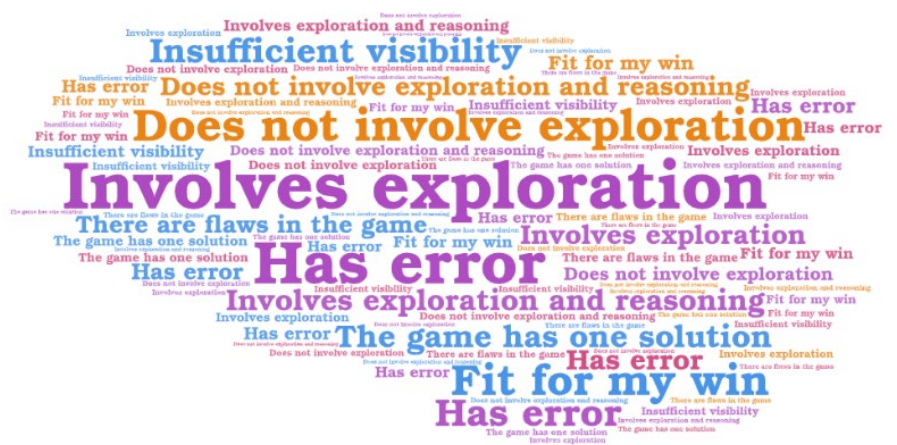

Figure 5. The Word Cloud of Exploration and Reasoning Theme

As can be seen in Figure 5, as the reason for the scores that the teachers gave to the exploration and reasoning theme in the games; They expressed opinions in the codes that it is suitable for the learning outcome, the game has only one solution, it includes exploration, it contains errors and it does not include discovery. Especially the G1 coded game was found to be less sufficient by all teachers except one teacher. When the reasons why the games were found to be insufficient, they stated that they could not see any situation in terms of exploration for the G3 coded game, but since the balls falling from the air required decision-making in a certain time, the students would improve their quick reasoning ability. For the G12 coded game, it was mentioned that the scale model activities could be given more space and therefore, the students could learn the relationship between the "conservation of balance" and the "equal" sign more meaningfully. When the reasons why the games were found to be sufficient were examined, it was stated that if the games were developed, they could be very sufficient for exploration and reasoning. They stated that for the G12 coded game, it was quite suitable for exploration in terms of design, but the game could not be completed due to the deficiencies in code blocks and puppets. In the games, the explanations made by the teachers regarding the connection theme are combined in common codes and given as a word cloud in Figure 6.

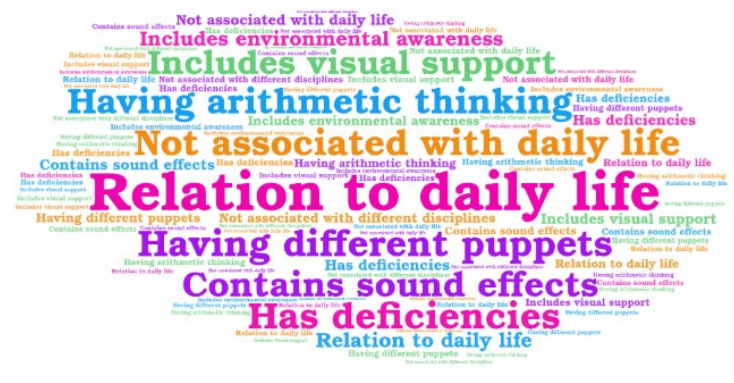

Figure 6. The Word Cloud of Connection Theme

As can be seen in Figure 6, as the reason for the scores given by the teachers to the connection theme in the games; They expressed opinions in the codes of being different puppets, containing environmental awareness, being associated with daily life, having arithmetic thinking, not including different disciplines, not being associated with daily life and having deficiencies. G4, G6 and G8 coded games were generally found to be very sufficient. When the reasons why these games were found to be very sufficient were examined, it was stated that for the G4 coded game, the presence of story content in the game would arouse interest in the students and the game was suitable for the students' daily life experiences. He stated that for the G6 coded game, choosing situations from daily life and supporting the problem situations used with visuals would be effective for the student to make connections. For the G8 coded game, it was stated that it is related to daily life and is a very good game for the development of environmental awareness. G1, G2 and G12 coded games were generally found to be less sufficient. Examining the reasons why these games were found to be less than sufficient, it was stated that there was no connection with daily life for these games and no connection was made with different lessons for the G12 game. In the games, the explanations made by the teachers regarding the strategy theme are combined in common codes and given as a word cloud in Figure 7. 


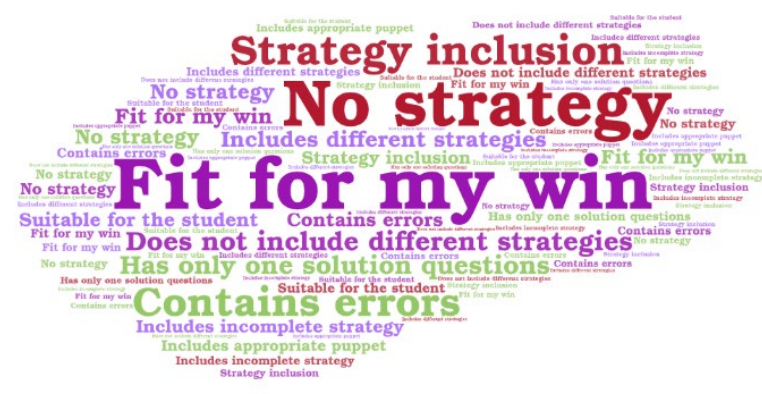

Figure 7. The Word Cloud of Strategy Theme

As can be seen in Figure 7, as the reason for the scores given by the teachers to the strategy theme in the games; They expressed their opinions in the codes of being suitable for the student, containing different strategies, being suitable for the learning outcome, containing appropriate puppets, containing errors, being one solution, and incomplete strategies. G1, G2, G3, G5, G9, G10 and G11 coded games were generally found to be less sufficient. When the reasons why these games were found to be less sufficient were examined, it was stated that there was no situation to reveal different strategies, there was no situation that allowed the student to develop a strategy, and it was based on a single method. When the reasons why these games were found to be very sufficient were examined, it was mentioned that they were open to the use of different methods and were suitable for the strategy for the target and behavior. In the games, the explanations made by the teachers regarding the participation theme are combined in common codes and given as a word cloud in Figure 8.

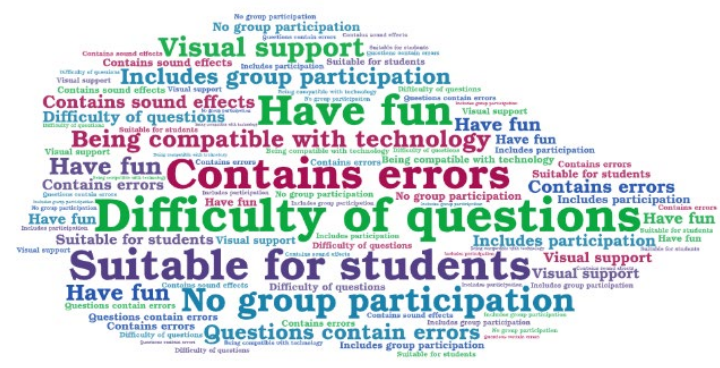

Figure 8. The Word Cloud of Participation Theme

As can be seen in Figure 8, as the reason for the scores given by the teachers to the participation theme in the games; They expressed their opinions in the codes that it is visually supported, suitable for technology, entertaining, includes group participation, suitable for students, questions that are difficult, does not include group participation, and contains errors. G1, G2, G3, G4, G10, G11 and G12 games were found to be less sufficient in this theme. The reasons why these games were found to be insufficient were stated as the difficulty of progressing the game for G1 and not using the direction keys instead of the movement keys w, $\mathrm{a}, \mathrm{s}, \mathrm{d}$. It has been stated that the emphasis on individuality for G2 and the constant repetition of the questions in the game will negatively affect participation. It was stated that the questions for G3 should start from simple. For G4, it was stated that the presence of mistakes in some questions would decrease the participation of the students. It was stated that the absence of a lecture section for G10 and the absence of the class's views would reduce participation. For the G11, it was thought that being individual would be an obstacle to participation. It has been stated that the emphasis on individuality for the G12 will reduce participation. In general, the reasons why the games are sufficient are stated as follows. It has been stated that the visuals and stories of the games will support participation in the lesson. It was stated that the games being computer games, the selection of cartoon characters, and the various visual and auditory elements used would attract the attention of the students. It is stated that there are games that will ensure the participation of the whole class with visual effects and selected problems. In the games, the explanations of the teachers about the interesting theme are combined in common codes and given as a word cloud in Figure 9. 


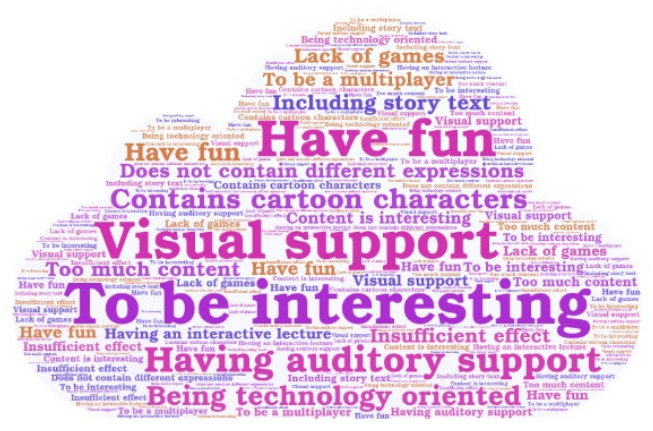

Figure 9. The Word Cloud of Interesting Theme

As can be seen in Figure 9, as the reason for the points given by the teachers to the interesting theme in the games; They expressed opinions in the codes that it contains story text, technology-oriented, interactive narration, interesting content, visually supported, auditory support, cartoon characters and not different expressions. Most of the games were found sufficient and very sufficient in their interesting theme. Only three games were found to be less than sufficient. These games are G1, G10 and G11 coded games. The reasons why these games were found to be less sufficient were stated that there should not be a lecture part for G10, the lecture part was too long, and this situation could cause the students to get bored. It is also stated that adding sound and effects to the game can make the game more interesting. For G11, it was thought that students could ask why crab ate hamburger. It was stated that the reasons why the games were found sufficient were that the visual, auditory and interactive nature of the games made them interesting. It was stated that the use of mutual conversations and the context and story text in the game would attract the attention of the students. In the games, the explanations made by the teachers regarding the understandable theme are combined in common codes and given as a word cloud in Figure 10.

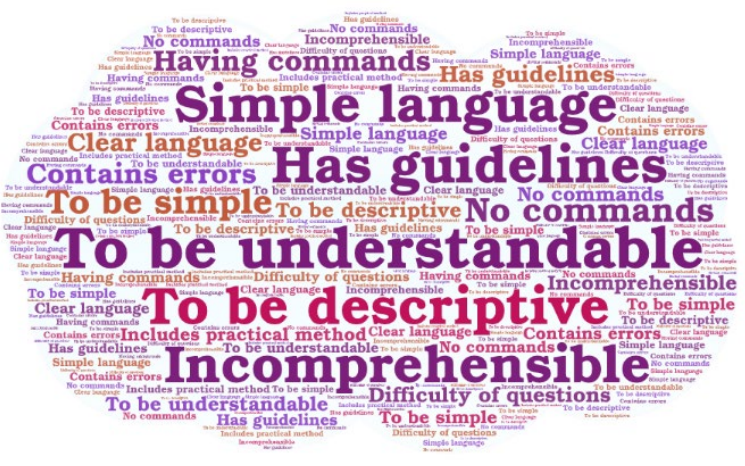

Figure 10. The Word Cloud of Comprehensible Theme

As can be seen in Figure 10, as the reason for the scores given by the teachers to the comprehensible theme in the games; They expressed their opinions about the codes being explanatory, having instructions, plain language, being understandable, being at a simple level, not having commands, not being comprehensible, and containing errors. Except for two of the designed games (G4, G6), the others were found sufficient and very sufficient in the theme of intelligibility. The teacher, who found these games to be less sufficient, stated that there were errors in the use of parentheses in the G4 coded game as a reason. He stated that this situation may cause the student to not fully understand the subject. For G6, it was stated that the questions were not intelligible. When we look at the reasons for finding the games sufficient, it is stated that the game instructions and problem situations are understandable, the questions are written in a plain language, and the language is simple and understandable. In the games, the explanations made by the teachers regarding the instructive and reinforcing theme are combined in common codes and given as a word cloud in Figure 11. 


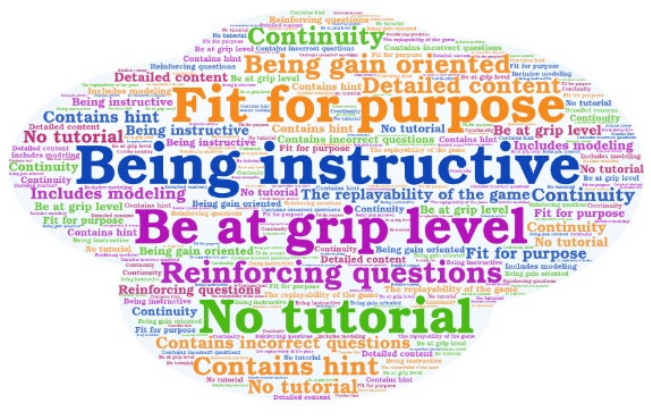

Figure 11. The Word Cloud of Educational and/or Reinforcing Theme

As can be seen in Figure 11, as the reason for the scores given by the teachers to the educational and/or reinforcing theme in the games; They expressed opinions in the codes that the outcome is instructive, comprehension level, questions are reinforcing, suitable for its purpose, the game is repeatable, contains hints, is outcome-oriented, not instructive, and contains incorrect questions. Most of the games were found to be sufficient and very sufficient in the theme of instructive and reinforcing. Only three games were found to be less than sufficient by the same participant. The games coded as G4, G5 and G13 are the games coded as G4, G5 and G13. It is seen that the explanations are included. On the other hand, it was found to be very sufficient by five participants because it included different examples in the game coded G2. In the games, the explanations made by the teachers regarding the evaluation theme are combined in common codes and given as a word cloud in Figure 12.

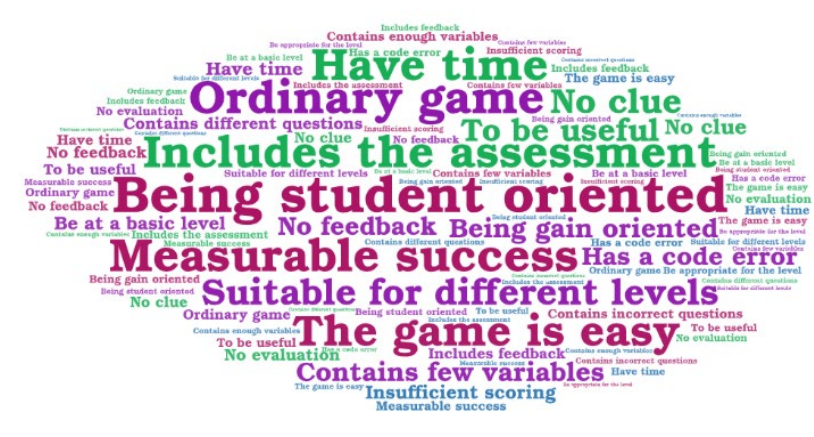

Figure 12. The Word Cloud of the Evaluation Theme

As can be seen in Figure 12, as the reason for the scores given by the teachers to the evaluation theme in the games; They expressed opinions in the codes that there is a time limit, that it includes evaluation, that it is student-oriented, that it is suitable for different levels, that success is measurable, that the game is ordinary, that the game is easy, that it contains few variables and that scoring is insufficient. Most of the games were found very adequate and sufficient. Seven games were found to be less sufficient. Games that are found to be less sufficient are G2, G3, G4, G5, G7, G10 and G12 coded games. Except for the G2 coded game, the other games were found to be less sufficient by the same participant. Examining the reasons why the games were found to be under-sufficient, the use of only true and false evaluation for the G3 coded game, the use of only the score variable for the G4 and G5 coded games, the direct passing without any hints when the wrong answer is given for the G7 coded game, and any evaluation for the G10 coded game were examined. He explained that he gave these points because there was no situation and he found the evaluation insufficient for the G12 coded game. In the games, the explanations made by the teachers regarding the usage theme are combined in common codes and given as a word cloud in Figure 13. 


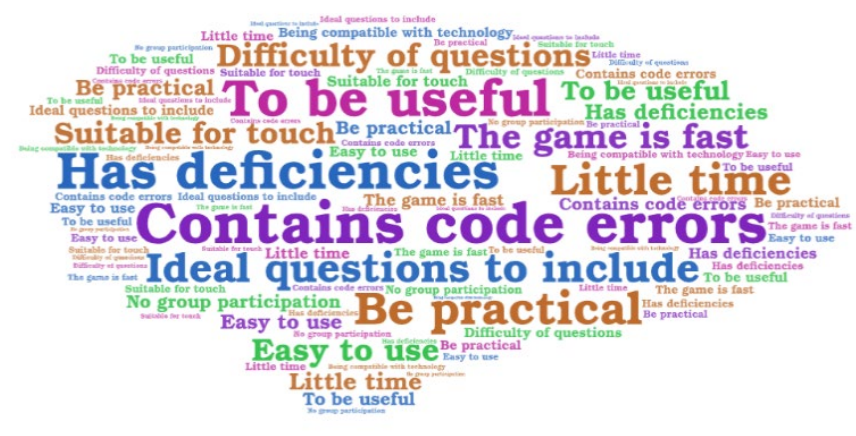

Figure 13. The Word Cloud of Usage Theme

As can be seen in Figure 13, as the reason for the scores given by the teachers to the usage theme in games; They expressed their opinions in the codes of being practical, useful, suitable for technology, containing ideal questions, suitable for touch, containing code errors, having deficiencies and difficult questions. Most of the games were found sufficient and very sufficient. In this theme, the game coded G1 was found to be less than sufficient by four participants. It is seen that the G1 game is found to be insufficient due to reasons such as code error, not working properly, some questions not appearing and the keys used are letter keys. On the other hand, G11 and G13 coded games were found very sufficient by five participants each. Since the participants found these games easy, practical and ideal, they thought that teachers could use them in the classroom. In the games, the explanations made by the teachers regarding the level theme are combined in common codes and given as a word cloud in Figure 14.

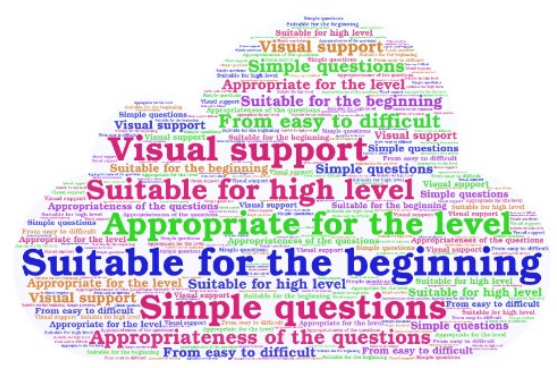

Figure 14. The Word Cloud of Level Theme

As can be seen in Figure 14, as the reason for the scores the teachers gave to the level theme in the games; They expressed their opinions in the codes that it is suitable for the level, easy to difficult, simple questions, suitable for the beginner, suitable for the upper level, and having visual support. Most of the games were found to be very adequate. Only G1, G3, G4 and G8 coded games were found sufficient. Most of the teachers stated that this theme was appropriate for the level. Among the shortcomings, it was stated that the questions in the G3 and G7 coded game appeal to senior students and that the questions are difficult. In the game coded G4, a teacher stated that the questions were difficult to begin with. In the game coded G6, three teachers stated that it can be used at all levels. In the games, the explanations made by the teachers regarding the theme of originality are combined in common codes and given as a word cloud in Figure 15.

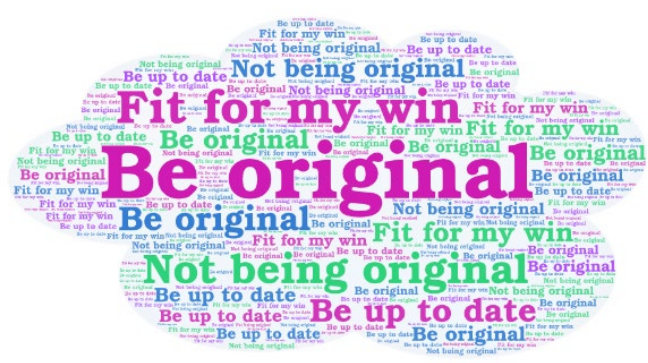

Figure 15. The Word Cloud of Originality Theme 
As can be seen in Figure 15, as the reason for the scores given by the teachers to the originality theme in the games; They expressed their opinions in the codes of being appropriate for the learning outcome, being original, being up-to-date and not being original. The games were generally evaluated as sufficient and very adequate. G1 coded game was found to be less sufficient. In the game coded G3, two teachers stated that the questions in the game were classic and frequently encountered before. G5, G6 and G8 coded games were found to be very sufficient. In the game coded G2, three teachers found the game original and successful according to the subject. In the game coded G8 and G10, three teachers found the game original and creative. Only one teacher stated that he did not find it original in the game coded G11 and G13. In the games, the explanations made by the teachers regarding the theme of time are combined in common codes and given as a word cloud in Figure 16.

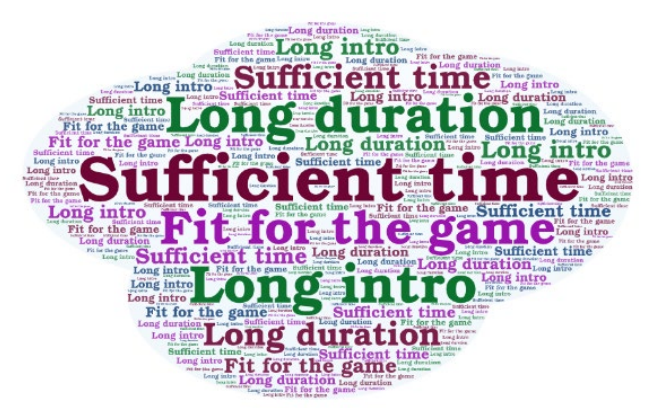

Figure 16. Word Cloud of the DurationTheme

As can be seen in Figure 16, as the reason for the scores given by the teachers to the duration theme in the games; They expressed opinions in their codes that the duration is sufficient, it is suitable for the game, the entrance is long and the duration is long. It is stated that the time in the games is very sufficient. In the game coded G3, a teacher stated that the students should be given a little more time, that is, the time should be extended a little more because the apples in the game fall very quickly. On the contrary, another teacher stated that the four-hour period given for the G3 coded game is too much and that it may cause students to get bored in the lesson because it is a repetitive game. It is striking that the G1 and G5 coded game is found to be less sufficient in the duration category. In the G1 coded game, three teachers stated that the time given for the game was too much. In the game coded G4, the teacher stated that the introduction part was too long.

\section{Results, Conclusions and Recommendations}

When the games designed by the pre-service teachers were examined pedagogically, while the games were generally considered very adequate in terms of problem solving, interesting, level and duration; exploration and reasoning, connection, strategy, participation, usage and originality were found to be less sufficient. The fact that the games designed by the mathematics teachers in Öztürk's (2021) study were generally sufficient in terms of problem solving and level themes coincide with the result of this study. The reason why the pre-service teachers had difficulties in the themes of strategy, connection and originality in the games they designed could be shown as the difficulty of the pre-service teachers in setting up the game scenario. Similar results were found in the study conducted by Yıldız Durak and Karaoğlan Yılmaz (2019) with prospective mathematics teachers. Based on this result; in digital game design, it is recommended to carry out studies in order to eliminate the deficiencies of the pre-service teachers especially in the themes that they get one point, in other words, they are less sufficient. Especially the strategy theme is important in game design. Studies in the literature also draw attention to strategy. For example, Arsal (2009) also drew attention to teaching the use of different strategies. Altun and Arslan (2006) also stated that learning and using different strategies was also effective in developing a positive attitude towards mathematics. Based on this result, it can be suggested that pre-service mathematics teachers could include problem situations that will reveal different strategies in the games they designed by using Scratch. Another result of the research was that some of the games designed by the pre-service teachers were found to be less sufficient in connection theme. Accordingly, it can be said that the pre-service teachers couldnot use the situations related to daily life in the games they designed as it was desired. This result is in parallel with 
the study of Öztürk (2021), and Öztürk revealing that the games in the field of algebra learning of mathematics teachers are insufficient in the theme of strategy. Games involving daily life situations are generally more liked and attracted by students. In the curriculum published by the Ministry of National Education (2018), the skill of associating with daily life was frequently emphasized. There are many studies stating that students have difficulties especially in the field of learning algebra (Akkaya \& Durmuş, 2006; Erdem \& Sarpkaya Aktaş, 2018; Ersoy \& Erbaş, 2005). In this case, it can be said that the use of daily life situations in mathematics teaching can help learning mathematics better, increase students' interest in the lesson, and provide the opportunity to integrate mathematics with daily life. Similar to these results, Gainsburg (2008) and Wubbels, Korthagen, and Broekman (1997) concluded in their studies that daily life situations could be used in mathematics teaching. In line with these results, it is thought that using daily life situations would reduce students' prejudices against mathematics, they would trust themselves and would provide a fun learning environment. When the usage of the theme was examined, some teachers emphasized that they could use these designed games in their lessons, while others stated that they could not use them in their lessons due to missing instructions, code errors, and the lack of a program. From this point of view, it can be said that these errors or deficiencies can be eliminated in order for the designed digital games to be used by teachers.

When the total scores of the games designed by the pre-service teachers re evaluated as a result of the evaluation, it could be said that all of the games were found sufficient by the mathematics teachers. This result shows that pre-service teachers' skills in designing digital games are sufficient. In this study, the number of samples was limited and pre-service teachers were asked to evaluate the games they designed from the perspective of mathematics teachers. However, teacher reflections about the digital games designed by the teacher candidates and using them in the classroom environment due to the Covid 19 epidemic could not be examined. It is recommended that researchers who can design study about this $u$ conduct design-based research on larger samples, especially with teacherstaking active roles in their classrooms.

\section{References}

Akbay, B. Ataş, H., \& Turan, B.Y. (Ed.) (2015). Çocuklar için scratch programlama (1. Baskı). İstanbul: Abaküs Yayıncilık.

Akçay, A. O. \& Sayar, N. (2019, Ekim). Sınıf öğretmenlerinin matematik öğretiminde teknoloji kullanımına ilișkin algılarının incelenmesi. 2. Uluslararası Temel Eğitim kongresinde sunulan tam metin bildiri (s.16-23), Muğla.

Akgün, L. (2007). Değiş̧ken kavramına ilişskin yeterlilikler ve değişken kavramının öğretimi. (Yayımlanmamış doktora tezi). Atatürk Üniversitesi Fen Bilimleri Enstitüsü, Erzurum.

Akkan, Y., Baki, A., \& Çakıroğlu, Ü. (2012). 5-8. sınıf öğrencilerinin aritmetikten cebire geçiş süreçlerinin problem çözme bağlamında incelenmesi. Hacettepe Üniversitesi Ĕ̆itim Fakültesi Dergisi, 43, 01-13.

Akkaya, R. \& Durmuş, S. (2015). İlköğretim 6. sınıf öğrencilerinin cebir öğrenme alanındaki kavram yanılgılarının giderilmesinde çalışma yapraklarının etkililiği. Dumlupınar Üniversitesi Sosyal Bilimler Dergisi, 27, 1-16.

Akkaya, R. \& Durmuş, S. (2006). İlköğretim 6-8. sınıf öğrencilerinin cebir öğrenme alanındaki kavram yanılgıları. Hacettepe Üniversitesi Ĕ̈itim Fakültesi Dergisi, 31(2), 1-12.

Akkaya, R. (2006). İlköğretim altıncı sınıf öğrencilerinin cebir öğrenme alanında karşılaştıkları kavram yanılgılarının giderilmesinde etkinlik temelli yaklaşımın etkililiği. (Yayımlanmamış yüksek lisans tezi). Abant İzzet Baysal Üniversitesi Sosyal Bilimler Enstitüsü, Bolu.

Aksoy, N. C. (2014). Dijital oyun tabanlı matematik öğretiminin ortaokul 6. Sınıf öğrencilerinin başarılarına, başarı güdüsü, öz-yeterlik ve tutum özelliklerine etkisi. (Yayımlanmamış doktora tezi). Gazi Üniversitesi, Eğitim Bilimleri Enstitüsü, Ankara

Aksoy, N. C. \& Küçük Demir, B. (2019). Matematik öğretiminde dijital oyun tasarlamanın öğretmen adaylarının yaratıcılıklarına etkisi. Gazi Eğitim Fakültesi Dergisi, 39(1). 147-169.

Alkan, C. (1984). Eğitim teknolojisi. Ankara: Aşama Matbaacıllk.

Altın, H. M. \& Kalelioğlu, F. (2015). Fatih Projesi ile ilgili öğrenci ve öğretmen görüşleri. Başkent University Journal of Education, 2(1), 89-105. 
Altun, M. \& Arslan, Ç. (2006). İlköğretim öğrencilerinin problem çözme stratejilerini öğrenmeleri üzerine bir çalışma. Uludağ Üniversitesi Eğitim Fakültesi Dergisi 19(1), 1-21.approaches (Third Edition). Thousand Oaks, CA: Sage Publications, Inc.

Arabacıoğlu, C., Bülbül, H., \& Filiz, A. (2007, Şubat). Bilgisayar programlama öğretiminde yeni bir yaklaşım. Akademik Bilişim Konferansı'nda sunulmuş tam metin bildiri (s.193-197), Dumlupınar Üniversitesi Kütahya.

Arsal, Z. (2009). Problem çözme stratejilerinin problem çözme başarısını yordama gücü. Abant İzzet Baysal Üniversitesi Eğitim Fakültesi Dergisi, 9(1), 103-113.

Başarmak, U. \& Hamutoğlu, N. B. (2019). Ortaokul öğrencilerinin “Kod adı 2023" proje eğitimi konusundaki görüşleri. Gazi Ĕ̆itim Bilimleri Dergisi, 5(özel sayı), 55-66.

Belet Boyacı, Ş. D. \& Güner Özer, M. (2019). Öğrenmenin geleceği: 21. yüzyll becerileri perspektifiyle Türkçe dersi öğretim programları. Anadolu Journal of Educational Sciences International(AJESI), $9(2), 708-738$.

Chmiliar, I. (2010). Multiple-case designs. In A. J. Mills, G. Eurepas \& E. Wiebe (Eds.), Encyclopedia of case study research (pp 582-583). USA: SAGE Publications.

Chuang, T. Y. \& Chen, W. F.(2007).Effects of digitalgames on children's cognitive achievement. Journal of Multimedia, 2(5), 27-30.

Çağıltay, N. E. \& Fal, M. (2013). Scratch ile programlamayı öğreniyorum (4. Baskı). Ankara: ODTÜ Yayıncillk.

Çatlak, Ş., Tekdal, M., \& Baz, F. Ç. (2015). Scratch yazılımı ile programlama öğretiminin durumu: bir doküman inceleme çalışması. Journal of Instructional Technologies \& Teacher Education. 4(3), 13-25.

Çakmak, M.(2000). İlköğretimde matematik öğretimi ve aktif öğrenme teknikleri. Gazi Üniversitesi Eğitim Fakültesi Dergisi, 20(3),119-131.

Çelik, L. (2007). Öğretim materyallerinin hazırlanması ve seçimi. Öğretim teknolojileri ve materyal geliştirme (Ed. Ö. Demirel \& E. Altun). Ankara: Pegem Yayıncılık

Çelik, D. \& Güneș, G. (2013). Farklı sınıf düzeyindeki öğrencilerin harfli sembolleri kullanma ve yorumlama seviyeleri. Kuram ve Uygulamada Eğitim Bilimleri, 13(2), 1157-1175.

Çubukluöz, Ö. (2019). 6. sınıf öğrencilerinin matematik dersindeki öğrenme zorluklarının Scratch programıyla tasarlanan matematiksel oyunlarla giderilmesi: bir eylem araştırması. (Yayımlanmamış yüksek lisans tezi). Bartın Üniversitesi Eğitim Bilimleri Enstitüsü, Bartın.

De Freitas, S. (2006). Learning in immersive worlds: A review of game-based learning. Erişim tarihi: 05.08.2021, http://researchrepository.murdoch.edu.au/id/eprint/35774/1/gamingreport_v3.pdf.

Dede, Y. \& Argün, Z. (2003). Cebir öğrencilere niçin zor gelmektedir?. Hacettepe Üniversitesi Eğitim Fakültesi Dergisi, 24(1), 180-185.

Dede, Y., Yalın, H. İ., \& Argün, Z. (2002, Eylül). İlköğretim 8. sınıf öğrencilerinin değişken kavramının öğrenimindeki hataları ve kavram yanılgıları. V. Ulusal Fen Bilimleri ve Matematik Eğitimi Kongresi. Ankara: ODTÜ.

Denner, J. Werner, L., \& Ortiz, E. (2012). Computer game screated by middle school girls: Can they be used to measure understanding of computer science concepts?.Computers \& Education, 58(1), 240-249.

Dienes, Z. P. (1971). An example of the passage from the concrete to the manipulation of formal systems. Educational Studies in Mathematics, 3(3), 337-352.

Erdem, Ö. \& Sarpkaya-Aktaş, G. (2018). Ortaokul 7. sınıf öğrencilerinin cebir öğrenme alanında yaşadıkları kavram yanılgılarının giderilmesinde etkinlik temelli öğretimin değerlendirilmesi. Turkish Journal of Computer and Mathematics Education, 9(2), 312-338.

Ersoy, H., Madran, R., \& Gülbahar, Y. (2011). Programlama dilleri öğretimine bir model önerisi: robot programlama. Akademik Bilişim 2011 Konferansı, Malatya: İnönü Üniversitesi.

Ersoy, Y. \& Erbaş, A. K. (2005). Kassel projesi cebir testinde bir grup Türk öğrencinin genel başarısı ve öğrenme güçlükleri. İlköğretim Online, 4(1), 18-39.

Ertaş, A. (2006). Biyolojide mikroskobik yapılar ve mikroorganizmalarla ilgili önemli kavramlara iliş̧in ders materyali geliştirme.(Yayımlanmamış yüksek lisans tezi). Yüzüncü Yıl Üniversitesi, Fen Bilimleri Enstitüsü, Van.

Eski, M. (2011). İlköğretim 7. sınıflarda cebirsel ifadeler ve denklemlerin öğretiminde probleme dayalı ögrrenmenin etkisi. (Yayımlanmamış yüksek lisans tezi). Kastamonu Üniversitesi Fen Bilimleri Enstitüsü, Kastamonu.

Frenkel, E. (2013). Love and Math: The heart of hidden reality. NY: Basic Books.

Fronza, I., Janes, A., Sillitti, A., Succi, G., \& Trebeschi, S. (2013). Cooperation wordle using preattentive processing techniques. 6th International Workshop on Cooperative and Human Aspects of Software Engineering (CHASE). (pp. 57-64). San Francisco, CA, USA. 
Gainsburg, J. (2008). Real-world connections in secondary mathematics teaching. Journal of Mathematics Teacher Education, 11(3), 199-219.

Gee, J. P. (2014). What video games have to teach us about learning and literacy. New York, NY: Palgrave Macmillan.

Gelibolu M.F. (2009). Gerçekçi matematik eğitimi yaklaşımıyla geliştirilen bilgisayar destekli mantık ögretimi materyallerinin 9.sınıf matematik dersinde uygulanmasının değerlendirilmesi. (Yayımlanmamış yüksek lisans tezi). Ege Üniversitesi Fen Bilimleri Enstitüsü, İzmir.

Guzdial, M. (2004). Programming environments for novices. In S. Fincher, \& M. Petre (Eds.), Computer science education research (pp. 127-154). Lisse, The Netherlands: Taylor \& Francis.

Gürman, Ü. (2019). Arduino ile müzik eğitiminde materyal tasarımı. (Yayımlanmamış yüksek lisans tezi). Afyon Kocatepe Üniversitesi, Sosyal Bilimler Enstitüsü, Afyon.

Higher Education Council (HEC), (2018). https://www.yok.gov.tr/kurumsal/idari-birimler/egitimogretim-dairesi/yeni-ogretmen-yetistirme-lisans-programlari. Erişim tarihi:[28.04.2021]

İnan, C. (2006). Matematik öğretiminde materyal geliştirme ve kullanma. Dicle Üniversitesi Ziya Gökalp Eğitim Fakültesi Dergisi, 7(2), 47-56.

Iskrenovic-Momcilovic, O. (2020). Improving Geometry Teaching with Scratch. International Electronic Journal of Mathematics Education, 15(2), 1-8.

Kaya, M. F. (2019). İlkokul öğretim programlarının teknoloji entegrasyonu bakımından incelenmesi. Eskişehir Osmangazi Üniversitesi Sosyal Bilimler Dergisi, 3(özelsayı), 1063-1091.

Keçeci, G., Alan, B., \& Kırbağ-Zengin, F. (2018). Eğitsel bilgisayar oyunları destekli kodlama öğrenimine yönelik tutum ölçeği: geçerlilik ve güvenirlik çalışması. Education Sciences (NWSAES),11(3), 184-194.

Kert, S. B. \& Uğraş, T. (2009, Ekim). Programlama eğitiminde sadelik ve eğlence: scratch örneği. The First International Congress of Educational Research, İstanbul: Ylldız Teknik Üniversitesi.

Kiili, K. (2005). Digital game-based learning: Towards an experiential gaming model. Internet and Higher Education, 8(1), 13-24.

Köse-Yavuzsoy, N. (2008). İlköğretim 5. sınıf öğrencilerinin dinamik geometri yazılımı Cabri geometriyle simetriyi anlamlandırmalarının belirlenmesi: bir eylem araştırması. (Yayımlanmamış doktora tezi). Anadolu Üniversitesi, Eğitim Bilimleri Enstitüsü. Eskişehir.

Lacampagne, C. (1995). Conceptual framework for the algebra initiative of the national instutute on student achievement, curriculum and assesment. In C. Lacampagne, W. Blair, \& J. Kaput (Eds.). The algebra initiative colloquium, 2, 237-242.

Lahtinen, E., Ala-Mutka, K., \& Jarvinen, H. M. (2005). A study of the difficulties of novice programmers. Proceedings of the 10th annual SIGCSE conference on Innovation and technology in computer science education. New York.

Landis, J. R. \& Koch, G. G. (1977). The measurement of observer agreement for categorical data. Biometrics, $33,1159-1174$.

Li, Q., Lemieux, C., Vandermeiden, E., \& Nathoo, S. (2013). Are you ready to teach secondary mathematics in the 21st century? A study of preservice teachers' digital game design experience. Journal of Research on Technology in Education, 45(4), 309-337.

Mercan, M. \& Aktaș, M. (2018). 6. sınıf matematik dersine ait cebirsel ifadeler konusunun scratch destekli öğretiminin öğrenci başarısına etkisi. International Social Sciences Studies Journal, 4(28), 63956409.

Mercan, M. (2019). 6. Sinıf matematik dersine ait "tam sayılar ve cebirsel ifadeler" konularının scratch destekli öğretiminin akademik başarı, motivasyon ve bilgilerin kalıcllı̆ına etkisi. (Yayımlanmamış doktora tezi).Gazi Üniversitesi Eğitim Bilimleri Enstitüsü, Ankara.

Miles, M. B. \& Huberman, A. M. (1994). Qualitative data analysis. Boston, USA: PearsonEducation.

Ministry of National Education [MoNE], (2017). Ortaokul matematik dersi (5, 6, 7 ve 8. Siniflar) siniflar ögretim programı ve kılavuzu. Ankara: Talim ve Terbiye Kurulu Başkanlığı.

Ministry of National Education [MoNE], (2018). Matematik dersi ögretim programı (1-8 sinıflar). Ankara: MEB Yayınları.

National Council of Teachers of Mathematics. (1989). Curriculum and evaluation standards for school mathematics. Reston, Va: Author.

Obut, S. (2005). İlköğretim 7.Sınıf maddenin içyapısına yolculuk ünitesindeki atomun yapısı ve periyodik çizelge konusunun eğitsel oyunlarla bilgisayar ortamında öğretimi ve buna yönelik bir model geliştirme.(Yayımlanmamış yüksek lisans tezi).Celal Bayar Üniversitesi Fen Bilimleri Enstitüsü, Manisa.

Özgen, K. \& Obay, M. (2008, Mayıs). Ortaöğretim matematik öğretmen adaylarının eğitim teknolojisine ilişkin tutumları. $8^{\text {th }}$ International Educational Technology Conference, Eskişehir. 
Öztop, F. \& Toptaş, V. (2017). İlkokul 4. sınıf öğrencilerinin matematik dersine yönelik korkusu ve altında yatan sebepler. International Journal of Education Technology and Scientific Researches, 2(3), 162173.

Öztürk, A. (2021). Ortaokul matematik öğretmenlerinin Scratch programıyla tasarladıkları oyunların ögrretmen ve öğrenci görüşleri doğrultusunda incelenmesi: Cebirden yansımalar. (Yayımlanmamış yüksek lisans tezi). Bartın Üniversitesi Lisansüstü Eğitim Enstitüsü, Bartın.

Pala, F. K. \& Mıhcı Türker, P. (2019). Öğretmen adaylarına programlama eğitimine yönelik görüşleri. Kuramsal Eğitimbilim Dergisi, 12(1), 116-134.

Papert, S. (1980). Mindstorms. NY. Basic Books.

Prensky, M. (2001). Digital game-based learning. New York: McGraw-Hill,

Ramani, P. \& Patadia, H (2012). Computer Assisted Instruction in Teaching of Mathematics. Journal of Humanities and Social Science, 2(1), 39-42.

Sarama, J. \& Clements, D. H. (2009). Early childhood mathematics education research: learning trajectories for young children. New York: Routledge.

Sarıçam, U. (2019). Dijital oyun tabanlı STEM uygulamalarının öğrencilerin STEM alanlarına ilgileri ve bilimsel yaratıcılı̆ı üzerine etkisi: Minecraft örneği. (Yayımlanmamış yüksek lisans tezi). Marmara Üniversitesi, Eğitim Bilimleri Enstitüsü, İstanbul.

Sarıtaş, M. (2007). Öğretim teknolojileri ve materyal tasarımı. Ankara: Pegem Yayıncıllk.

Shin, S. \& Park, P. (2014). A study on the effect affecting problem solving ability of primary students through the scratch programming. Advanced Science and Technology Letters, 59, 117-120.

Soylu, Y. (2008). 7. Sınıf öğrencilerinin cebirsel ifadeleri ve harf sembollerini(değişkenleri) yorumlamaları ve bu yorumlamada yapılan hatalar. Selçuk Üniversitesi Ahmet Keleşoğlu Eğitim Fakültesi Dergisi, 25(1),237-248.

Szlávi, P. \& Zsakó, L. (2006). Programming versus application. In: Mittermeir, R.T. (Ed.), ISSEP 2006, LNCS $4226,48-58$.

Şahin, T. Y. \& Yıldırım, S. (1999). Öğretim teknolojileri ve materyal geliştirme. Ankara: Anı Yayınları.

Tarman, B. \& Baytak, A. (2011). Teknolojinin eğitimdeki yeni rolü: sosyal bilgiler öğretmen adaylarının bakış açıları. Gaziantep Üniversitesi Sosyal Bilimler Dergisi, 10(2), 891-908.

Taşlıbeyaz, E. (2010). Ortaöğretim öğrencilerinin bilgisayar destekli matematik öğretiminde matematik algılarına yönelik durum çalışması: lise 3.sınıf uygulaması. (Yayımlanmamış yüksek lisans tezi). Atatürk Üniversitesi Fen Bilimleri Enstitüsü, Erzurum.

The Digital Education Action Planında (2021-2027). Retrieved from: https://ec.europa.eu/education/education-in-the-eu/digital-education-action-plan_en

Tutkun, Ö.F., Öztürk B., \& Demirtaş, Z., (2011, Nisan). Matematik öğretiminde bilgisayar yazılımları ve etkililiği 2nd International Conference on New Trends in Education and Their Implications konferansında sunulan sözlü bildiri, Antalya.

Turkish Language Association [TLA]. Bilim ve sanat terimleri ana sözlügü. https://sozluk.gov.tr. Erişim tarihi:[28.07.2021]

Usta, N. \& Gökkurt Özdemir, B. (2018). Ortaokul öğrencilerinin cebirsel düşünme düzeylerinin incelenmesi. Eğitimde Nitel Araştırmalar Dergisi, 6(3), 427-453.

Varinlioğlu, G., Alankuş, G., Aslankan, A., \& Mura, G. (2019) Oyun tabanlı öğrenme ile digital mirasın yayginlaştırılması. METU Journal Of The Faculty Of Architecture, 36(1), 23-40.

Wubbels, T., Korthagen, F., \& Broekman, H. (1997). Preparing teachers for realistic mathematics education. Educational Studies in Mathematics, 32, 1-28.

Yalvaç, B. (2019). Sekizinci sınıf ögrrencilerinin cebir öğrenme alanında matematiksel dili kullanma becerilerinin incelenmesi. (Yayımlanmamış yüksek lisans tezi). Hacettepe Üniversitesi Eğitim Bilimleri Enstitüsü, Ankara.

Yelbay, Y. (2015). Sözcük bilgisi öğretimi. N. Bekleyen (Ed.) Dil öğretimi içinde (s.352-367). Ankara: Pegem Akademi.

Yıldırım, Ali \& Șimşek, H. (2008). Sosyal bilimlerde nitel araștırma yöntemleri. Ankara: Seçkin Yayınevi.

Yıldız Durak, H. \& Yılmaz, F. G. K. (2019). Öğretmen adaylarının matematik öğretimine yönelik eğitsel dijital oyun tasarımlarının ve tasarım sürecine ilişkin görüşlerinin incelenmesi. Ege Eğitim Dergisi, 20(1), 262-278.

Yıldız, P., Koza Çiftçi, Ș., Şengil Akar, Ș., \& Sezer, E. ( 2015). Ortaokul 7. sınıf öğrencilerinin cebirsel ifadeleri ve değişkenleri yorumlama sürecinde yaptıkları hatalar. Eğitim Araștırmaları Dergisi, 8(1), 18-31.

Yılmaz, Ș. (2019). Scratch programı öğretiminde birlikte öğrenme tekniği kullanımının öğrencilerin akademik başarısına ve öz yeterlik algısına etkisi. (Yayımlanmamış yüksek lisans tezi). Afyon Kocatepe Üniversitesi Fen Bilimleri Enstitüsü, Afyon. 
Yüksel, S. (2015). Öğretmen yetiştirme politikalarında dönüşüm: 21. yy öğretmenini yetiştirme. Türkiye Özel Okullar Birliği Dergisi, 8(2), 23-28.

Additon-1 Screenshots of the same games

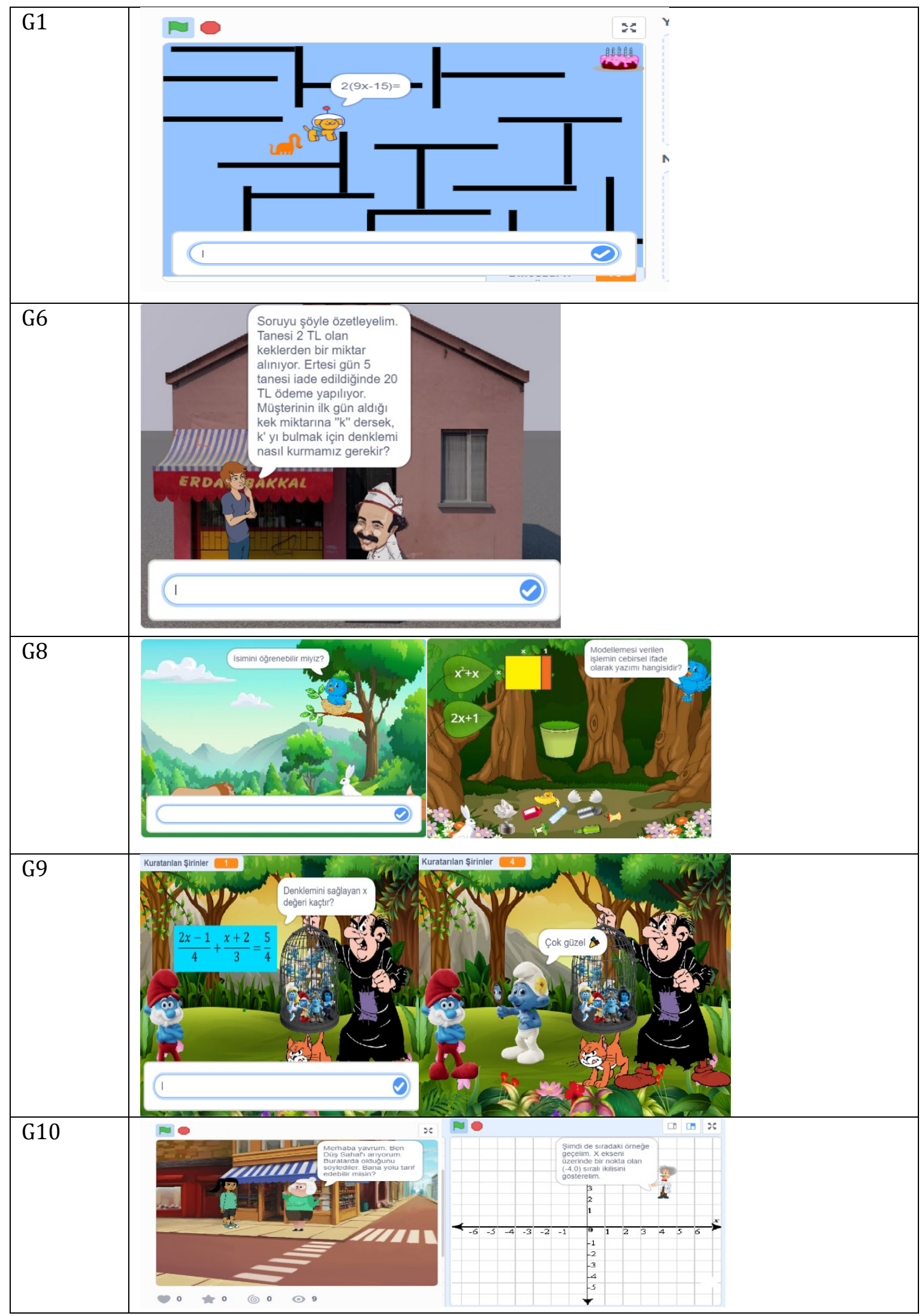

